DOI https://doi.org/10.30525/978-9934-26-073-5-1-66

\title{
СЛОВОТВІРНІ ПРОЦЕСИ У ВОКАБУЛЯРІ ШКОЛЯРІВ (НА МАТЕРІАЛІ НІМЕЦЬКОЇ МОВИ)
}

\author{
Поздняков О. В. \\ кандидат філологічних наук, доцент, \\ доцент кафедри іноземних мов і країнознавства, \\ факультет туризму \\ Прикарпатського національного університету \\ імені Василя Стефаника \\ м. Івано-Франківськ, Україна
}

Одним із важливих джерел збагачення лексичного складу сучасної німецької мови (зокрема, іiі розмовного варіанту) є слова та вирази, первинно притаманні сфері спілкування представників відповідних вікових груп і соціальних прошарків.

До зазначених мовних субсистем належить вокабуляр школярів, одиниці якого характеризується формальною незвичністю, з одного боку, та експресивно-оцінним забарвленням значення - 3 іншого. Така лексика відзначається, як правило, прагматичною цінністю застосування на рівні побутових комунікативних ситуацій.

Як засвідчує огляд наукових публікацій 3 обраної проблематики, окремі аспекти формування, структури, семантики, сфер функціонування лексики школярів зокрема та молоді загалом були предметом вивчення низки вітчизняних і зарубіжних (насамперед, німецьких та німецькомовних) лінгвістів [2, 3, 4, 7]. У свою чергу, мета нашого дослідження виокремлення основних особливостей словотвірних процесів лексикографічно зафіксованої частини словникового запасу школярів - передбачає також з'ясування позамовних детермінант формування досліджуваного вокабуляру.

Актуальність пропонованого дослідження зумовлена стрімким зростанням популярності використання лексики школярів в усній та писемній формах спілкування, засобах масової інформації, соціальних мережах, а також їх фіксації в лексикографічних джерелах літературної німецької мови, що вважається вищим етапом розвитку мовного знака, передбачаючи його вживання без врахування специфіки контексту чи стилістичних маркувань [5, с.834]. Таким чином, матеріалом нашого дослідження стала вибірка із словників сучасної німецької мови $[8,9,10]$. 
Суттєвий вплив на формування та зміни словникового запасу школярів віком від 12-13 до 18-19 років здійснюють позамовні, зокрема фізіологічні та соціальні чинники. До перших слід віднести процес статевого дозрівання, до других - трансформацію системи цінностей, яка спричинює появу нових соціальних (групових, субкультурних) ролей.

У даному контексті варто зазначити, що вказаний вище період $\epsilon$ фазою переходу від сімейних цінностей до групових. У цей час спостерігається різке зменшення авторитету дорослих (батьків) та зростання впливу груп однолітків (так званих «peer groups»). Школярі відчувають потребу набуття бажаного статусу в групі, приймаючи основні елементи iii діяльності. 3 іншого боку, зростає потреба виокремлення з-поміж представників інших субкультурних угруповань, відмежування від останніх, що відбувається за допомогою поведінки, зовнішнього вигляду, а також вербально.

У процесі запозичення вокабуляру школярів до сфери комунікації, позбавленої групових, вікових та субкультурних рамок, провідну роль відіграють засоби масової інформації. Тут на перший план виступає прагматична цінність досліджуваної лексики. Остання використовується насамперед 3 метою привернення уваги, емоційного впливу, вираження суб'єктивного (позитивного чи негативного) ставлення.

3 іншого боку, нестандартність одиниць аналізованої мовної субсистеми є перешкодою для їх входження до словникового складу літературної німецької мови. Дослідники вказують на існування лише потенційної можливості кодифікації та стандартизації цих мовних одиниць [3, с. 182]. По-перше, це зумовлено яскравим експресивно-оцінним забарвленням зазначених лексем. По-друге, левова частка аналізованого вокабуляру не задовільняє потреби первинної номінації, отже, носить субстандартний характер та має відповідне стилістичне маркування. У проаналізованих нами лексикографічних джерелах ці слова мають позначку «Schülersprache» («лексика школярів»).

Вивчення процесу утворення вокабуляру школярів показує продуктивність словотвірних моделей, притаманних словотвору літературної німецької мови [6, с. 103]. Це вважаємо закономірним, позаяк досліджуваний лінгвістичний феномен попри найменування «Schülersprache» не $\epsilon$ окремою мовною системою.

Специфічною ознакою утворення лексики школярів $\epsilon$ метафоризація, яка відбувається паралельно із словотвірними процесами. Таким чином, відбуваються зміни семантики твірних основ лексичних одиниць літературної німецької мови та іï субсистем. Наприклад, слово Kloster у досліджуваному вокабулярі зафіксовано в значенні Kabinett. У даному 
випадку помітне метафоричне пренесення найменування на основі подібності за функцією.

Це саме стосується й процесу запозичення з інших мов (насамперед 3 англійської). Так, слово killern (англ. to kill - töten) зазнає семантичного переосмислення та використовується у значенні einen Tintenfleck löschen. Причиною популяризації таких лексичних одиниць є зростаючий вплив англійської мови як засобу міжнародної комунікації, а також походження значної кількості молодіжних субкультур.

Аналіз лексикографічних джерел продемонстрував використання у словотвірних процесах продуктивних i частотних для словотвору літературної німецької мови афіксів і напівафіксів [1]. Особливо продуктивними є суфіксація (Spicker - jemand, der spickt) та напівпрефіксація (nachbrummen - nachsitzen), котрі, як правило, супроводжуються метафоризацією твірних основ (abbohren, abpinnen - abschreiben).

Важливе місце у формуванні вокабуляру школярів відіграє абревіація. Серед зафіксованих скорочень переважають усічення. Такі мовні одиниці позначають актуальні для представників досліджуваної соціально-вікової групи найменування осіб (Rex-Direktor), а також навчальних предметів (Franz-Französischunterricht).

Отже, важливою ознакою словотвірних процесів у лексиці школярів $\epsilon$ використання семантично переосмислених (метафоризованих) твірних основ. Метафоризація є в даному випадку зручним засобом вербального вираження групової приналежності, демонстрації неповторності (оригінальності), відмежування на фоні інших членів німецькомовного комунікативного простору.

Субсистемність досліджуваного вокабуляру детермінує схильність до використання продуктивних для літературної німецької мови словотвірних моделей. Дистинктивною ознакою в цьому випадку виступає зміна значення коренів або їх видозміна шляхом усічення.

Вважаємо, що отримані в результаті дослідження результати можуть бути застосовані при вивченні особливостей функціонування вокабуляру школярів, зокрема реалізації зафіксованих у словниках лексичних значень аналізованих мовних одиниць в усному та письмовому дискурсі.

\section{Література:}

1. Словарь словообразовательных элементов немецкого языка. 2-е изд., стереотип. / А.Н. Зуев, И.Д. Молчанова, Р.З. Мурясов и др.; под рук. М.Д. Степановой. Москва : Русский язык, 2000. 536 с. 
2. Христенко О.С. Німецький молодіжний сленг: лінгвокогнітивний та соціолінгвістичний аспекти : канд. філол. наук : 10.02.04 / Нац. б-ка України ім.. В.І. Вернадського. Київ, 2009.

3. Androutsopoulos J.K. Und jetzt gehe ich chillen : Jugend- und Szenesprachen als lexikalische Erneuerungsquellen des Standards // L. Eichinger, W. Kallmeyer. Standardvarianten. Wie viel Variation verträgt die deutsche Sprache. Berlin; New York : de Gruyter, 2005. S. 171-206.

4. Henne H. Jugend und ihre Sprache : Darstellung, Materialien, Kritik. Berlin; New York : de Gruyter, 1986. 385 S.

5. Mattheier K., Allgemeine Aspekte einer Theorie des Sprachwandels // W. Besch u. a. Sprachgeschichte. Aufl. 2. Berlin; New York : 1998. Teilbd. 1. S. 824-836.

6. Stepanova M.D., Černyševa I.I. Lexikologie der deutschen Gegenwartssprache. Москва : Академия, 2003. 256 c.

7. Wehrli Ch. Anglizismen in BRAVO. Eine empirische Untersuchung mit Schülern / Ch. Wehrli. Zürich : Studentendruckerei, 2002. 234 S.

\section{Список лексикографічних джерел:}

8. Duden - Das große Wörterbuch der deutschen Sprache. Aufl. 4. Mannheim : Bibliographisches Institut, 2012.

9. Duden - Deutsches Universalwörterbuch. Aufl. 7. Mannheim : Bibliographisches Institut, 2011.

10. Küpper H. Wörterbuch der deutschen Umgangssprache. Warszawa : Rea; Stuttgart : Ernst Klett Verlag für Wissen und Bildung, 1996. 960 S. 